\title{
Detection and Characterization of Multi Drug-resistant Extended-spectrum and pAmpC Beta-lactamases Producing Escherichia coli from Chicken Meat in West Bengal, India
}

\author{
Kunal Batabyal $^{1 *}$, Abhiroop Banerjee ${ }^{1}$, Samir Dey ${ }^{1}$, Indranil Samanta ${ }^{1}$, \\ Devi Prasad Isore ${ }^{1}$ and Abhishek Dharm Singh ${ }^{2}$
}

\author{
${ }^{1}$ Department of Veterinary Microbiology, Faculty of Veterinary and Animal Sciences, \\ West Bengal University of Animal and Fishery Sciences, \\ Kolkata - 37, West Bengal, India \\ ${ }^{2}$ Department of Veterinary Public Health, F/VAS, West Bengal University of Animal and \\ Fishery Sciences, Kolkata - 37, West Bengal, India
}

*Corresponding author

\section{A B S T R A C T}

\begin{tabular}{l}
\hline K e y w o r d s \\
Antibiogram, \\
bla $a_{\mathrm{AmpC}}$, bla $a_{\mathrm{CTX}-\mathrm{M}}$, \\
Chicken meat, \\
E. coli, ESBL \\
\hline Article Info \\
\hline $\begin{array}{l}\text { Accepted: } \\
\text { 05 June } 2020 \\
\text { Available Online: } \\
\text { 10 July } 2020\end{array}$ \\
\hline
\end{tabular}

Antimicrobial resistance can be seen in almost all pathogenic bacteria present in food like chicken meat, leading to treatment failure in human patients and serious public health problems. The present study aimed to detect extended-spectrum beta-lactamases (ESBLs) and AmpC beta-lactamase (ACBL)-producing Escherichia coli from chicken meat, from different parts of West Bengal. A total of 113 raw chicken meat samples were collected during slaughter from different local markets followed by isolation and identification by standard conventional and molecular methods. About79\% samples were positive for $E$. coli and among 89 isolates $17(19.1 \%$ ) were positive to ESBL property and presence of the bla $_{\text {СTX-M gene, whereas }} 78$ strains $(87.6 \%)$ were found to possess $b l a_{\mathrm{AmpC}}$ gene. Antibiogram study of ESBL positive E. coli strains revealed resistance of these strains to ceftriaxone, ampicillin (both 100\%), amoxicillin/clavulanic acid, ceftazidime, cefotaxime, tetracycline (all approx. 94\%), azithromycin (70.6\%) and norfloxacin $(64.7 \%)$ in-vitro whereas imipenem (94\%), amikacin (82\%), gentamicin $(58.8 \%)$ and ampicillin/sulbactam (71\%) were quite effective against these MDR isolates. So, about $79 \%$ of chicken meat samples were found to be contaminated with $E$. coli, most of which were resistant to commonly used antibiotics which may lead to animal and human health hazards.

\section{Introduction}

India is annually producing 5.3 million metricton of meat i.e. the $5^{\text {th }}$ largest in the World (DAHD, 2017) with the world's largest livestock population which plays an important role in rural economy and livelihood. It produces $21 \%$ of global chicken meat production annually. The poultry industry is a high growing vertically integrated industry in India and as well as in the state of West Bengal. West Bengal is the $2^{\text {nd }}$ largest contributor with 640 thousand metric ton meat production of which chicken meat 
production is 328 thousand metricton (DAHD, 2017). But chicken meat can easily get spoilt with bacterial spoilage which may come from faulty handling, improper storage and poor management of the birds (Dierikx et al., 2010).

Global consumption of drugs, especially antibiotics, has increased tremendously in last few decades leading to rise in their resistance among microbial populations. The incidence of extended-spectrum beta-lactamases (ESBLs)-producing Escherichia coli in food is quite significantly increasing nowadays all around the World. ESBL production in bacteria is governed by the presence of bla $a_{\mathrm{CTX}-\mathrm{M}}, b l a_{\mathrm{SHV}}$, and $b l a_{\mathrm{TEM}}$ genes which are easily transferred from one bacterium to another spreading the antimicrobial resistance. Among these resistance genes, the bla $a_{\text {CTX-M }}$ gene is the most common gene associated with ESBL positivity in the $E$. coli (Dierikx et al., 2010). This multidrugresistant (MDR) pathogen can create a major problem during their treatment forcing the clinicians to use newer and newer antibiotics (Tenover et al., 1999; Olesen et al., 2004).This is leading to the increased use of last-resort antimicrobials such as carbapenems even for non-life threatening infections. These antimicrobial resistance genes of $E$. coli are easily transferrable to other pathogens conferring them resistance. In a study in Mexico, Castillo et al., (2018) revealed that MDR E. coli associated with urinary tract infections $(63 \%)$ of human beings were highly resistant $(27-48 \%)$ to commonly used antibiotics. AmpC betalactamase (ACBL) is the first bacterial enzyme reported to destroy penicillin in Gram-negative bacteria like Escherichia coli. ACBL encoding gene bla $a_{\mathrm{AmpC}}$ is found in transmissible plasmids and also in bacterial chromosomes (Reich et al., 2013).ACBL producing $E$. coli strains are resistant to broad-spectrum cephalosporins but their resistance patterns are less expressed in-vitro than that of the ESBLs (Jacoby, 2009).

Chicken meat is a very popular and common source of animal protein worldwide. ESBL producing $E$. coli is frequently reported from chicken samples worldwide and may be pathogenic to humans causing urinary tract infections, septicemia, meningitis etc. (Grami et al., 2013; Nandanwar et al., 2014). Most of the countries are using a large quantity of different antimicrobials to raise poultry which are also used in human treatments. Indiscriminate use of such essential antimicrobials in animal production is likely to accelerate the resistance development of pathogens, as well as commensal organisms like E. coli. This would result in treatment failures, economic loss and could act as a source of the gene pool for transmission to humans (Castanon, 2007). In addition, there are human health concerns about the presence of antimicrobial residues in meat, eggs, and other animal products (Sahoo et al., 2010; Darwish et al., 2013).

Identification of potential MDR pathogenic bacteria is essential towards the development of better managemental procedures. With this background, the present research has aimed atthe detection and characterization of ESBL and ACBL producing MDR E. coli from raw chicken meat collected from different local markets of West Bengal, India and followed by in-vitro antibiogram to assess their resistance patterns.

\section{Materials and Methods}

\section{Sample collection}

A total of 113 chicken meat samples were collected at the time of slaughter from local markets of Nadia and Hooghly district of West Bengal during the period September to November 2018. About $10 \mathrm{~g}$ of fresh meat 
samples were aseptically collected in individual vials and transported (under ice cover) to the laboratory. Primary isolation from the collected samples was attempted on the same day of collection.

\section{Bacteriological isolation and identification}

A $10 \%$ homogenized suspension of each meat sample was prepared in sterile normal saline and streaked on to MacConkey's agar (HiMedia, India) plates following overnight enrichment in nutrient broth. The plates were incubated overnight at $37^{\circ} \mathrm{C}$ and the representative lactose fermenting pinkish colonies were picked up and further streaked on sterile EMB agar (Hi-Media, India) plates. Colonies producing 'metallic sheen' were selected for further morphological (by Gram's staining) and biochemical identification (Quinn et al., 2011; Carter and Wise, 2004). One tentative $E$. coli isolate from each sample was taken in this study.

\section{PCR confirmation of Escherichia coli}

Identification of tentative $E$. coli isolates was confirmed from sequence of the $16 \mathrm{~S} r R N A$ gene specific for this bacterium, following the protocol of Wang et al., (1996) (Table 1). Briefly, genomic DNA was extracted from the over-night broth culture of $E$. coli by the conventional phenol-chloroform method. The 16S rRNA gene was amplified using specific bacterial primers and sequenced. Bacteria were tentatively identified by finding similarity of the sequences with SSU sequences in the NCBI GenBank and RPD (http://rdp.cme.msu.edu) databases.

\section{Phenotypic detection of ESBL in E. coli}

In-vitro detection of ESBL activity of the $E$. coli isolates was done by disc diffusion method (Bauer et al., 1966) using both cefotaxime $(30 \mu \mathrm{g})$ and ceftazidime disks $(30 \mu \mathrm{g})$ and their clavulanate $(10 \mu \mathrm{g})$ discs as per CLSI method of Patel et al., (2015). An increase of zone diameter $(>5 \mathrm{~mm})$ in each clavulanate disk than the single drug disk is treated as phenotypical confirmation of the ESBL activity.

\section{Molecular detection of ESBL property}

Molecular confirmation of ESBL was tested in all the phenotypical ESBL positive E.coli strains. Bacterial genomic DNAs were extracted following the protocol of Mahanti et

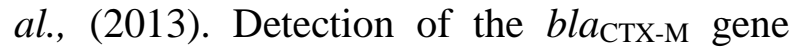
was done by PCR assay as per the protocol of Weill et al., (2004) (Table 1). In this method, $5 \mu 1$ bacterial DNA templates, $50 \mathrm{pmol}$ of each primer, $\quad 200 \mathrm{mM}$ deoxynucleoside triphosphate, $1 \mathrm{U}$ Taq DNA polymerase (Promega, USA), $2 \mathrm{mM} \mathrm{MgC1}_{2}$, and $10 \%$ dimethyl sulfoxide (DMSO) was added in a $25 \mu 1$ reaction mixture and subjected to amplification with following PCR conditions - 10mins of initial denaturation at $94^{\circ} \mathrm{C}$ followed by $30 \mathrm{~s}$ of denaturation at $94^{\circ} \mathrm{C}, 30 \mathrm{~s}$ of annealing at $53^{\circ} \mathrm{C}$ and $1 \mathrm{~min}$ of extension at $72^{\circ} \mathrm{C}$ for 35 cycles and $10 \mathrm{mins}$ of final extension at $72^{\circ} \mathrm{C}$. The amplified product was visualized by gel documentation system (UVP, UK) after electrophoresis in $1.5 \%$ $(\mathrm{w} / \mathrm{v})$ agarose (SRL, India) gel containing ethidium bromide $(0.5 \mu \mathrm{g} / \mathrm{ml})$ (SRL, India). In this study, an Escherichia coli serotype O2, maintained in the departmental laboratory and one Pseudomonas aeruginosa strain (ATCC 27853) were used as positive and negative control respectively.

\section{Phenotypical detection of ACBL} Production in Escherichia coli isolates

In-vitro ACBL activity of all Escherichia coli isolates was examined by cefoxitincloxacillin double-disc synergy (CC-DDS) test following the protocol of Tan et al., (2009). 


\section{PCR detection of AmpC gene in Escherichia coli}

All the CC-DDS positive E.coli strains were examined for the presence of the AmpC gene. Molecular detection of the $b l a_{\mathrm{AmpC}}$ gene was done in all the in-vitro ACBL positive Escherichia coli isolates was performed following the protocol of Feria et al., (2002) (Table 1). In this method, the total reaction volume was $25 \mu 1$ containing $5 \mu \mathrm{l}$ of bacterial DNA template, $100 \mathrm{pmol}$ of each primer, $200 \mathrm{mM}$ of each dNTP, $2 \mathrm{mM} \mathrm{MgCl}_{2}$, and $10 \%$ DMSO.

The PCR mixture was subjected to initial denaturation step of $5 \mathrm{mins}$ at $94^{\circ} \mathrm{C}$; followed by 30 cycles of amplification consisting of $30 \mathrm{~s}$ of denaturation at $94^{\circ} \mathrm{C}, 30 \mathrm{~s}$ of annealing at $57^{\circ} \mathrm{C}, 1 \mathrm{~min}$ of elongation at $72^{\circ} \mathrm{C}$ and $10 \mathrm{mins}$ of final extension at $72^{\circ} \mathrm{C}$. The PCR product was electrophoresed in $1.5 \%(\mathrm{w} / \mathrm{v})$ agarose (SRL, India) gel containing ethidium bromide $(0.5 \mu \mathrm{g} / \mathrm{ml})$ (SRL, India) and the gel was visualized in gel documentation system (UVP, UK).

\section{Antibiogram of ESBL gene positive $E$. coli}

In-vitro antibiotic sensitivity of the ESBL gene positive E. coli isolates was examined using 12 commonly used antimicrobials viz., ampicillin, amikacin, ampicillin/ cloxacillin, amoxicillin/clavulanic acid, ampicillin/ sulbactam, azithromycin, cefotaxime, ceftriaxone, ceftazidime, gentamicin, imipenem, and levofloxacin by disc diffusion method (Bauer et al., 1966). Fresh broth cultures of the positive isolates were poured on to sterile Mueller Hinton agar (Hi-Media, India) plates followed by uniform spreading. Standard antibiotic discs (Hi-Media, India) were used as the source of antibiotics. The inhibition zone diameters were interpreted following the standard chart (Patel et al., 2015).

\section{Results and Discussion}

A total of 113 chicken meat samples were examined and 89 (78.86\%) samples were tested positive for Escherichia coli. Identification of the isolates as E. coli was confirmed by their pinkish colonies on Mac Conkey's agar, characteristic 'metallic sheen' on EMB agar plates, Gram's staining and positive reaction to the indole test. Identification was further confirmed by their16S rRNA gene sequences (Figure I).This study identified very high prevalence (78.86\%) of Escherichia coli in poultry meat, which matches with earlier works of Reich $e t$ al., (2013), Maciuca et al., (2015) and Klimiene et al., (2018) who reported 45\%, $54 \%$ and $92 \%$ E. coli prevalence in chicken meat from different countries showing the significant presence of the pathogen in food chain (Dierikx et al., 2010). All the E. coli isolates in this study showed typical cultural, morphological, biochemical as well as the 16S rRNA gene sequences of $E$. coli (Quinn et al., 2011; Carter and Wise, 2004; Samanta, 2013).

By the in-vitro test, 17 (19.1\%) E. coli isolates were detected to be ESBL producers; by PCR reaction they possessed the bla $a_{\mathrm{CTX}-\mathrm{M}}$ gene (Figure II). A total of 78 (87.6\%) E. coli isolates were confirmed to be ACBL $\left(b l a_{\text {AmpC }}\right)$ producer both phenotypically and genotypically (Figure III, Table 2). E. coli strains isolated from Hooghly district's samples showed more positivity in both ESBL and ACBL categories. Sixteen (16) isolates were found to possess both the genes (Table 2) with again Hooghly district isolates showing higher frequency. Similar or higher ESBL positivity in poultry E. coli isolates have been reported from different countries by Klimiene et al., (2018), Casella et al., (2017), Tekiner and Ozpinar (2016) and Maamar et al., (2016). 
The gene $b a_{\text {СтХ-м }}$ is the most common and dominant gene among all ESBL genes (Feria et al., 2002; Samanta, 2013). The present study also confirms the earlier reports and identifies it as a potential threat for even human health also (Dierikx et al., 2013). The plasmid-mediated AmpC beta-lactamase enzyme is also highly prevalent (88\%) among the $E$. coli strains, and the prevalence rate was higher than those observed by Casella et al., (2017)(3.9\%) and Van et al., (2008) (23.7\%). Such a high prevalence of drug resistance genes in poultry E. coli may increase the risk of microbial drug-resistance development in animal and human pathogens (Borjesson et al., 2013).

Table.1 Target genes and their primers used in this study

\begin{tabular}{|c|c|c|c|}
\hline Gene & Primer sequence & Size & Reference \\
\hline E. coli $16 \mathrm{~S}$ rRNA & $\begin{array}{l}\text { ECO-1 F 5'GACCTCGGTTTAGTTCACAGA3' } \\
\text { ECO-2 R 5'CACACGCTGACGCTGACCA3' }\end{array}$ & $585 \mathrm{bp}$ & $\begin{array}{l}\text { Wang et } \\
\text { al.,1996 }\end{array}$ \\
\hline $\begin{array}{l}\text { bla }_{\text {CTX_M }} \quad \text { consensus } \\
\text { (ESBL) }\end{array}$ & $\begin{array}{l}\text { CTX-M F 5' CRATGTGCAGYACCAGTAA 3' } \\
\text { CTX-M R 5' CGCRATATCRTTGGTGGTG 3' }\end{array}$ & 540 bp & $\begin{array}{l}\text { Weill et al., } \\
\qquad 2004\end{array}$ \\
\hline$b l a_{\mathrm{AmpC}}(\mathrm{ACBL})$ & $\begin{array}{l}\text { AmpC F 5'CCCCGCTTATAGAGCAACAA3' } \\
\text { AmpC R 5’TCAATGGTCGACTTCACACC3' }\end{array}$ & $634 \mathrm{bp}$ & $\begin{array}{l}\text { Feria et al., } \\
\quad 2002\end{array}$ \\
\hline
\end{tabular}

Table.2 Frequency of antibiotic resistance and their gene distributions among E. coli isolates from chicken meat from different sampling locations in West Bengal, India

\begin{tabular}{|c|c|c|c|c|c|c|c|}
\hline \multirow{2}{*}{$\begin{array}{l}\text { Name of } \\
\text { the } \\
\text { Districts }\end{array}$} & \multirow{2}{*}{$\begin{array}{l}\text { No. of } \\
\text { meat } \\
\text { samples } \\
\text { screened }\end{array}$} & \multirow{2}{*}{$\begin{array}{c}\text { No. of } \\
E . \text { coli } \\
\text { strains } \\
\text { Isolated } \\
(\%)\end{array}$} & \multirow{2}{*}{$\begin{array}{c}\text { ESBL } \\
\text { positivity } \\
\text { in } E \text {. coli } \\
\text { strains } \\
(\%)\end{array}$} & \multirow{2}{*}{$\begin{array}{c}\text { ACBL } \\
\text { positivity } \\
\text { in } E \text {. coli } \\
\text { strains } \\
(\%)\end{array}$} & \multicolumn{3}{|c|}{$\begin{array}{l}\text { Gene distribution in positive } \\
\qquad \text { E. coli strains }\end{array}$} \\
\hline & & & & & $\begin{array}{l}\text { bla }_{\text {CTX-M }} \\
\text { only }\end{array}$ & $\begin{array}{c}\text { bla }_{\text {AmpC }} \\
\text { only }\end{array}$ & $\begin{array}{c}\text { bla }_{\mathrm{CTX}-\mathrm{M}}+ \\
\text { bla }_{\mathrm{AmpC}}\end{array}$ \\
\hline Nadia & 42 & $32(76.19)$ & $6(18.76)$ & $27(84.38)$ & 0 & 21 & 6 \\
\hline Hooghly & 71 & $57(80.28)$ & $11(19.29)$ & $51(89.47)$ & 1 & 41 & 10 \\
\hline Total & 113 & 89 (78.76) & $17(19.10)$ & 78 (87.64) & 1 & 62 & 16 \\
\hline
\end{tabular}


Table.3 Resistance pattern of 17 ESBL positive E. coli isolates obtained from chicken meat in West Bengal

\begin{tabular}{|c|c|c|c|c|c|c|c|}
\hline \multirow[t]{2}{*}{$\begin{array}{l}\text { Sl. } \\
\text { No. }\end{array}$} & \multirow[t]{2}{*}{$\begin{array}{l}\text { Antimicrobials } \\
\text { (Conc. in } \mu \mathrm{g})\end{array}$} & \multicolumn{2}{|c|}{$\begin{array}{l}\text { Isolates } \\
\text { sensitive }\end{array}$} & \multicolumn{2}{|c|}{$\begin{array}{c}\text { Isolates } \\
\text { intermediately } \\
\text { sensitive }\end{array}$} & \multicolumn{2}{|c|}{$\begin{array}{l}\text { Isolates } \\
\text { resistant }\end{array}$} \\
\hline & & No. & $\%$ & No. & $\%$ & No. & $\%$ \\
\hline 1. & Amikacin $(\mathrm{AK}-30)$ & 14 & 82.35 & 3 & 17.65 & 0 & 0 \\
\hline 2. & Amoxicillin / Clavulanic acid (AMC - 20/10) & 0 & 0 & 1 & 5.88 & 16 & 94.12 \\
\hline 3. & Ceftriaxone (CTR 30) & 0 & 0 & 0 & 0 & 17 & 100 \\
\hline 4. & Ampicillin/Sulbactam (A/S - 10/10 mcg) & 12 & 70.59 & 5 & 29.41 & 0 & 0 \\
\hline 5. & Ampicillin (AM - 10) & 0 & 0 & 0 & 0 & 17 & 100 \\
\hline 6. & Ceftazidime (CAZ - 30) & 0 & 0 & 1 & 5.88 & 16 & 94.12 \\
\hline 7. & Imipenem (IPM - 10) & 16 & 94.12 & 1 & 5.88 & 0 & 0 \\
\hline 8. & Gentamicin (GEN - 10) & 10 & 58.83 & 7 & 41.17 & 0 & 0 \\
\hline 9. & Norfloxacin (NX - 10) & 0 & 0 & 6 & 35.29 & 11 & 64.71 \\
\hline 10. & Cefotaxime (CTX - 30) & 0 & 0 & 1 & 5.88 & 16 & 94.12 \\
\hline 11. & Azithromycin (AZM - 15) & 3 & 17.65 & 2 & 11.76 & 12 & 70.59 \\
\hline 12. & Tetracycline (TE - 30) & 0 & 0 & 1 & 5.88 & 16 & 94.12 \\
\hline
\end{tabular}

Figure.1

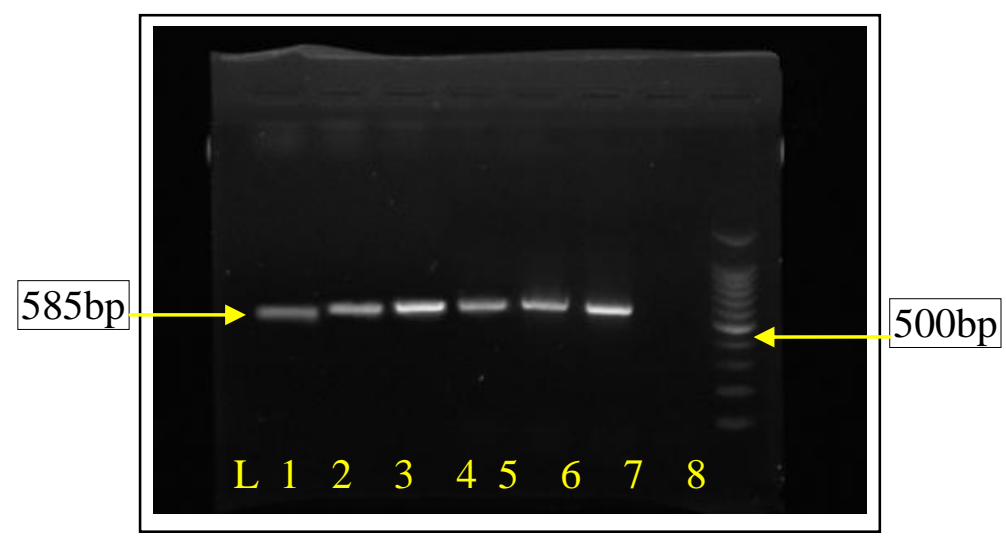

Figure.2

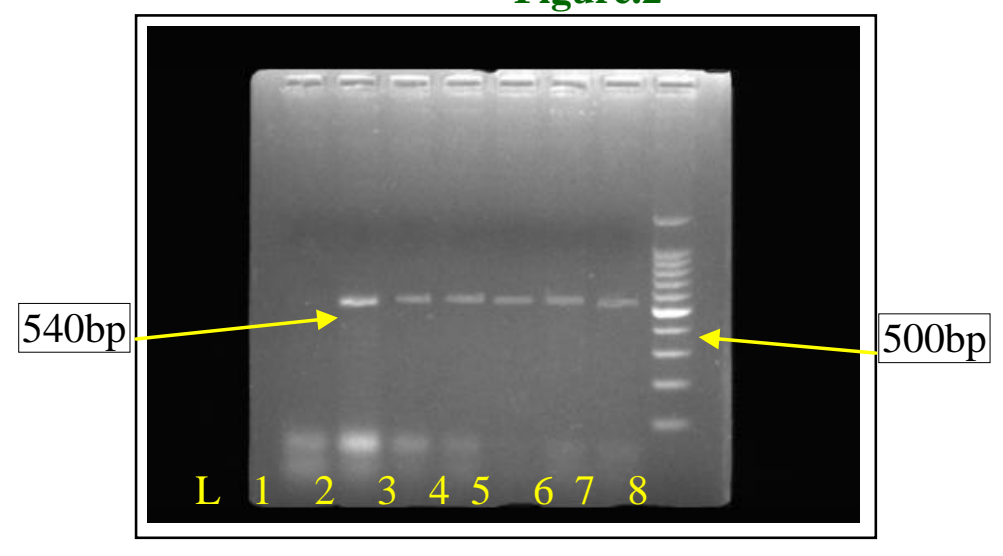


Figure.3

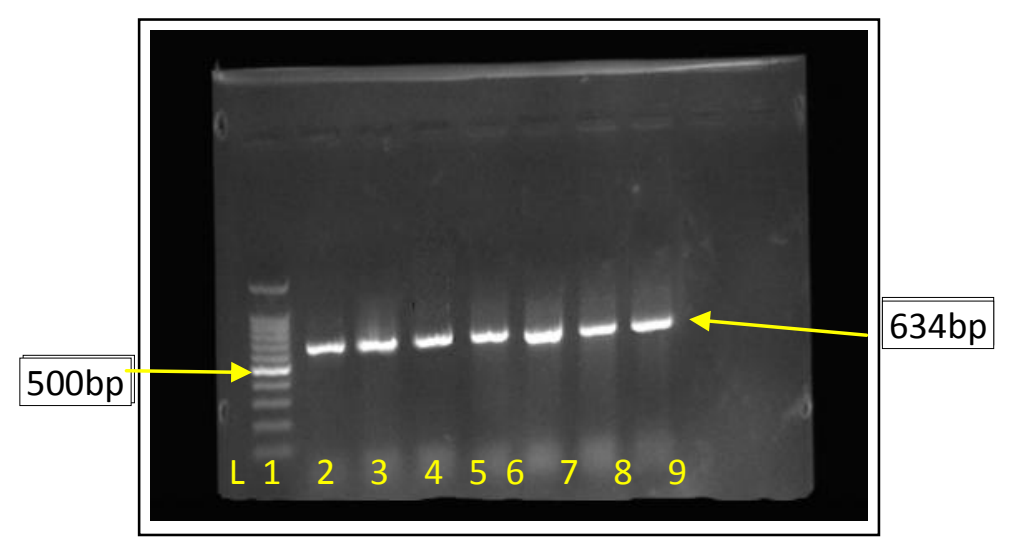

In-vitro antibiogram of the ESBL-positive E.coli isolates revealed multi-drug resistance with high-level (64-100\%) resistance to ampicillin, ceftriaxone, cefotaxime ceftazidime, amoxicillin-clavulanic acid (all beta-lactams), norfloxacin (fluoroquinolones) and azithromycin (macrolides), tetracycline (tetracycline) (Table 3). Isolates were however sensitive to drugs like amikacin, gentamicin, imipenem, and ampicillinsulbactam. The ESBL-positive E. coli isolates were resistant to most of the antimicrobials and thereby confirmed to possess MDR properties i.e. those were resistant to at least 3 different classes of antibiotics (Reich et al., 2013; Maamar et al., 2016; Van et al., 2008; Beninati et al., 2015). Again, Tekiner and Ozpinar (2016) reported that E. coli from raw chicken meat were resistant to cefotaxime $(62.1 \%)$, ceftazidime $(55.2 \%)$, cefoperazone $(51.7 \%)$ and cloxacillin $(20.6 \%)$. Van et al., (2008) also reported multidrug-resistance among poultry meat $E$. coli, which were resistant to tetracycline $(77.8 \%)$, ampicillin and amoxicillin (both 50.5\%),gentamicin $(24.2 \%)$ and norfloxacin (17.2\%) although few other studies indicated that ESBL positive E. coli strains are sensitive to few beta-lactams and aminoglycosides like amikacin, imipenem, ampicillin-sulbactam, and gentamicin (Castillo et al., 2018; Tekiner and Ozpınar, 2016). The high positivity of multidrug-resistant E. coli in human food items can increase the potential transmission risk of microbial drug resistance to human pathogens leading to treatment failure in near future. This rapid increase in the development and spread of antibiotic resistance is a matter of serious concern (Van et al., 2008; Ryu et al., 2012). In recent years, enough evidences are showing excessive use of antimicrobial agents and antimicrobial resistance from animals and poultry (Mathew et al., 2009). Antibiotic usage has increased markedly over the last few years with the intensification of poultry farming practices, in many countries including India (Castanon, 2007; Sahoo et al., 2010). Major reasons for use of antibiotics in food-producing animals include prevention and treatment of infections, growth promotion and improvement in production in the poultry farm (Mehdizadeh et al., 2010; Haldorsen et al., 2008).

Therefore it can be concluded that approx. $79 \%$ of the chicken meat samples examined in this study, were contaminated with E. coli; $19 \%$ and $87 \%$ of these bacteria were positive for ESBL and ACBL property. They were resistant to commonly used antimicrobials other than amikacin, imipenem, gentamicin, and ampicillin/sulbactam. This drug resistance even to third-generation cephalosporins in pathogens like Escherichia 
coli is increasing in India as well as in other countries raising serious concern for animal and human health.

\section{Acknowledgements}

The authors thank the Hon'ble ViceChancellor and DREF, WBUAFS for providing necessary funds and the Faculties of Department of Veterinary Microbiology, WBUAFS, West Bengal, India for the research facilities and support for this study. The staffs of the department (particularly Tilak Thapa) deserve special thanks for his help.

\section{Conflict of Interest}

No competing interest exists among the authors.

\section{References}

Bauer A.W., Kirby W.M., SherrrisJ.C.,Turck M. 1966. Antibiotic susceptibility testing by a standardized single disk method. American J. Clin.Pathol., 45(4):493-496.

Beninati C., Reich F.,Muscolino D., Giarratana F., PanebiancoA., KleinG., Atanassova V. 2015. ESBL-producing Bacteria and MRSA isolated from Poultry and Turkey Products imported from Italy. Czech J. Food Sci. 33(2):97102.

Borjesson, S., Egervarn M., Lindblad M., Englund S. 2013. Frequent Occurrence of Extended-Spectrum Beta-Lactamaseand Transferable AmpC BetaLactamase-Producing Escherichia coli on Domestic Chicken Meat in Sweden. Appl. Environ. Microbiol. 79(7):24632466.

Carter G.R., Wise D.J. 2004. Essentials of Veterinary Bacteriology and Mycology. $6^{\text {th }}$ edn., Iowa State Press, Pp. 129-134.
Casella T., Nogueira M.C.L., Saras E., Haenni M., MadecJ.Y.2017. High prevalence of ESBLs in retail chicken meat despite reduced use of antimicrobials in chicken production, France. Int. J. Food Microbiol. 257:271275.

Castanon J.I.R. 2007. History of the use of antibiotics as growth promoters in European poultry feeds. Poult. Sci. 86: 2466-2471.

Castillo R.F.Y., Moreno-Flores A.C., AvelarGonzález F.J., Márquez-Díaz F., Harel J., Guerrero-Barrera A.L. 2018. An evaluation of multidrug-resistant Escherichia coli isolates in urinary tract infections from Aguascalientes, Mexico: cross-sectional study. Ann. Clin. Microbiol.Antimicrob.17: 3440(https://doi.org/10.1186/s12941-0180286-5).

DAHD, A Study of India's Dairy Sector 2017: The World's Largest Producer and Consumer - Research and Markets. https://www.businesswire.com/news/ho me/20180102005671/en/Study-IndiasDairy-Sector-2017-Worlds-Largest. Accessed on 18/07/18, 8.25 PM IST.

Darwish W.S., Eldaly E.A., El-Abbasy M.T., Ikenaka Y., Nakayama S., Ishizuka M. 2013. Antibiotic residues in food: The African scenario. Japanese J. Vet. Res. 61: S13-S22.

Dierikx C., van Essen-Zandbergen A., Veldman K., Smith H., Mevius D. 2010. Increased detection of extendedspectrum beta-lactamase-producing Salmonella enterica and Escherichia coli isolates from poultry. Vet. Microbiol.145:273-278.

Dierikx C.M., van der Goot J.A., Smith H.E., Kant A., Mevius D.J. 2013. Presence of ESBL/AmpC-producing Escherichia coli in the broiler production pyramid: A descriptive study. PLoS One, 8: 79005. 
Feria C., Ferreira E., Correia J.D., Goncalves J., Canica M. 2002. Patterns and mechanisms of resistance to betalactams and beta-lactamase inhibitors in uropathogenic Escherichia coli isolated from dogs in Portugal. J. Antimicrob. Chemother. 49:77-85.

Grami R., Mansour W., Dahmen S., Mehri W., Haenni M., Aouni M., Madec J.Y. 2013. The blaCTX-M-1 IncI1/ST3 plasmid is dominant in chickens and pets in Tunisia. J. Antimicrob. Chemother. 68(12): 2950-2952.

Haldorsen B., Aasnaes B., DahlK.H., Hanssen A.M., Simonsen G.S., WalshT.R., Sundsfjord A., Lundblad E.W. 2008. The AmpC phenotype in Norwegian clinical isolates of Escherichia coli is associated with an acquired ISEcp1-like ampC element or hyperproduction of the endogenous AmpC. J. Antimicrob. Chemother. 62(4): 694-702 (doi:10.1093/jac/dkn257).

Jacoby G.A. 2009. AmpC-Lactamases. Clin.Microbiol. Rev. 22(1):161-182.

Klimiene I., Virgailis M., Kerziene S., Siugzdiniene R., Mockeliunas R., Ruzauskas M. 2018. Evaluation of genotypical antimicrobial resistance in ESBL producing Escherichia coli phylogenetic groups isolated from retail poultry meat. J. Food Safety.38:e12370 (https://doi. org/10. 1111/jfs.12370).

MaamarE., HammamiS., AlonsoC.A., DakhliN., AbbassiM.S., FerjaniS., HamzaouiZ., SaidaniM., TorresC., BoubakerI.B.2016. High prevalence of extended-spectrum and plasmidic AmpC beta-lactamase-producing Escherichia coli from poultry in Tunisia.Int. J. Food Microbiol. 231:6975.

Maciuca I.E., Williams N.J., Tuchilus C., Dorneanu O., Guguianu E., Carp-Carare C., Rimbu C., Timofte D. 2015. High prevalence of Escherichia coli- producing CTX-M-15 extendedspectrum beta-lactamases in poultry and human clinical isolates in Romania. Microb. Drug Resist. 21(6): 651-662 (doi: 10.1089/mdr.2014.0248. Epub 2015 Mar 3).

Mahanti A., SamantaI., BandopaddhayS., JoardarS.N., DuttaT.K., BatabyalS., SarT.K., Isore D.P. 2013. Isolation, molecular characterization and antibiotic resistance of Shiga ToxinProducing Escherichia coli (STEC) from buffalo in India. Lett. Appl. Microbiol. 56(4):291-298.

Mathew A.G., Liamthong S., Lin. J.2009. Evidence of Int1 transfer between Escherichia coli and Salmonella Typhi. Food Biol. 6(8): 959-964.

Mehdizadeh S., Kazerani H.R., Jamshidi A. 2010. Screening of chloramphenicol residues in broiler chickens slaughtered in an industrial poultry abattoir in Mashhad, Iran. Iranian J. Vet. Sci. Tech.2: 25-32.

Nandanwar N., Janssen T., Kuhl M., Ahmed N., Ewers C., Wieler L.H. 2014. Extraintestinal pathogenic Escherichia coli (ExPEC) of human and avian origin belonging to sequence type complex 95 (STC95) portray indistinguishable virulence features. Int. J. Med. Microbiol. 304(7): 835-842.

Olesen I., Hasman H., Aarestrup F.M. 2004. Prevalence of beta-lactamases among ampicillin-resistant Escherichia coli and Salmonella isolated from food animals in Denmark. Microb. Drug Resist. 10:334-340.

Patel J.B., Cockerill F.R., Bradford P.A., Eliopoulos G.M., Hindler J.A., Jenkins S.G., Lewis J.S., LimbagoB., Miller L.A., Nicolau D.P., Powell M., Swenson J.M., Traczewski M.M., Turnidge J.D., Weinstein M.P., Zimmer B.L. 2015. Clinical and Laboratory Standard Institute: Performance 
Standards for Antimicrobial

Susceptibility Testing; Twenty-Fifth informational supplement. CLSI document $\mathrm{M}_{100}-\mathrm{S}_{25}$. CLSI, Wayne, Pa, USA. 35(3):1-240.

Quinn P.J., Markey B.K., Leonard F.C., Fitz Patrick E.S., Fanning S., Hartigan P.J. 2011. Veterinary Microbiology and Microbial Diseases, $2^{\text {nd }}$ edn, Blackwell Publishing Ltd. Pp. 266-273.

Reich F., Atanassova V., Klein G. 2013. Extended-spectrum $\beta$-lactamase- and AmpC-producing enterobacteria in healthy broiler chickens, Germany. Emerg. Infect. Dis. 19:1253-1259.

Ryu S.H., Lee J.H., Park S.H., Song M.O., Park S.H., Jung H.W., Park G.Y., Choi S.M., Kim M.S., Chae Y.Z., Park S.G., Lee Y.K. 2012. Antimicrobial resistance profiles among Escherichia coli strains isolated from commercial and cooked foods. Int. J. Food Microbiol. 159: 263-266.

Sahoo K.C., Tamhankar A.J., Johansson E., Lundborg C.S. 2010. Antibiotic use, resistance development and environmental factors: A qualitative study among healthcare professionals in Orissa, India. BMC Publ. Hlth. 10: 629.

Samanta I. 2013. Chapter 6: Enterobacteriaceae, In: Veterinary Bacteriology .New India Publishing Agency, New Delhi - 110088. Pp. 119135.

Tan T.Y., Yong Ng L.S., He J., Koh T.H., Hsu L.Y. 2009. Evaluation of Screening
Methods to detect Plasmid-mediated AmpC in Escherichia coli, Klebsiella pneumoniae, and Proteus mirabilis. Antimicrob. Agents Chemother. 53(1): 146-149.

Tekiner I.H., Ozpınar H. 2016. Occurrence and characteristics of extendedspectrum beta-lactamases-producing Enterobacteriaceae from foods of animal origin. Braz. J. Microbiol. 47: 444-451.

Tenover F.C., Mohammed M.J., Gorton T.S., Dembek Z.F. 1999. Detection and reporting of organisms producing extended spectrum-beta-lactamases: survey of laboratories in Connecticut. J. Clin. Microbiol. 37:4065-4070.

Van T.T.H., Chin J., Chapman T., Tran L.T., Coloe P.J. 2008. Safety of raw meat and shellfish in Vietnam: An analysis of Escherichia coli isolations for antibiotic resistance and virulence genes. Int. J. Food Microbiol. 124:217-223.

Wang R., Cao W., Cerniglia C. 1996. PCR Detection and Quantitation of Predominant Anaerobic Bacteria in Human and Animal Fecal Samples. Appl. Environ. Microbiol. 62(4):12421247.

Weill F., ClaudeJ., DemartinM., CoignardS., Grimont P. 2004. Characterization of ESBL (CTX-M-15) producing strains of Salmonella enterica Isolated in France and Senegal. FEMS Microbiol. Lett. 238(2):353-358.

\section{How to cite this article:}

Kunal Batabyal, Abhiroop Banerjee, Samir Dey, Indranil Samanta, Devi Prasad Isore and Abhishek Dharm Singh. 2020. Detection and Characterization of Multi Drug-resistant Extended-spectrum and pAmpC Beta-lactamases Producing Escherichia coli from Chicken Meat in West Bengal, India. Int.J.Curr.Microbiol.App.Sci. 9(07): 80-89. doi: https://doi.org/10.20546/ijcmas.2020.907.009 